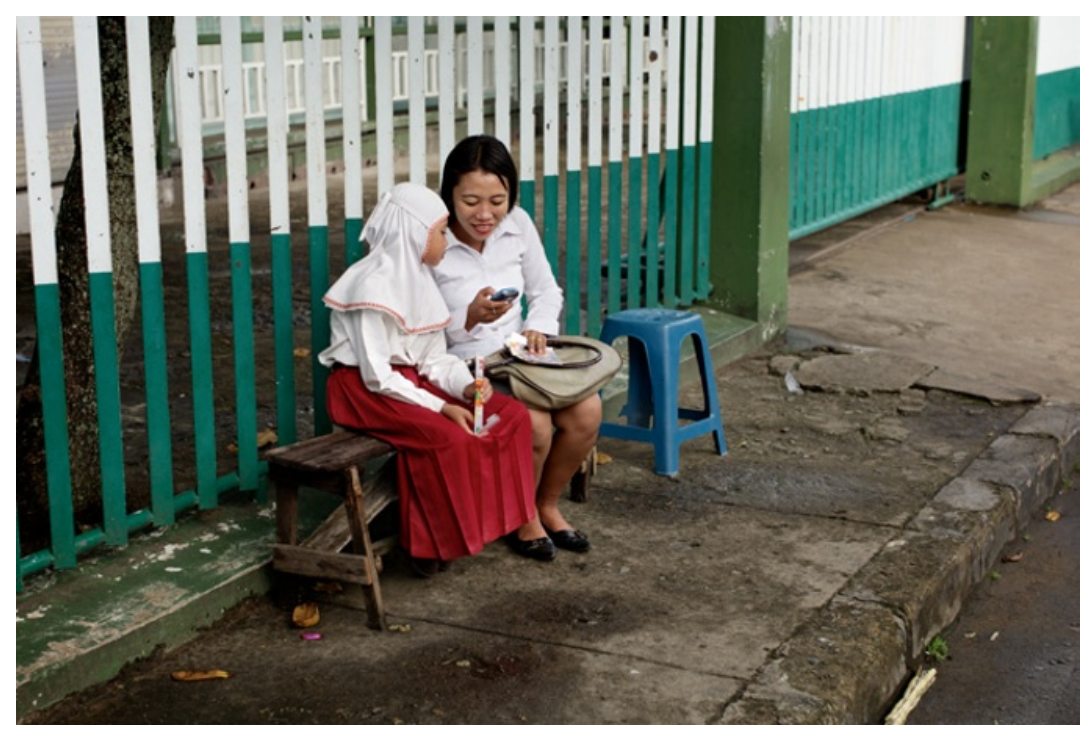

Fig. 8. PONTIANAK: An elementary teacher helps a forlorn student, waiting outside the schoolyard, arrange for a ride home.

June 2010: photo by S. Chris Brown 


\title{
BETWEEN THE GLOBAL AND THE LOCAL: NEGOTIATING ISLAM AND DEMOCRACY IN PROVINCIAL INDONESIA
}

\author{
Noorhaidi Hasan*
}

After 9/11 many observers saw the sprouting of religious symbols in public spaces of Indonesian provincial towns as an indication that Islam was undermining the country's secular democratic system. Some imagined a future as bleak as Pakistan or even Iraq today, countries that are gradually being sucked into a maelstrom of political and religious violence. But this alarmist perspective fails to capture the realities of post-Suharto Indonesia. The mushrooming of religious symbols is also coupled with the rise of a new middle class and the flourishing of democratic activities. Despite the fact that some sceptics still judge Indonesia's emergent democracy as superficial and procedural rather than functional, one cannot deny that the electoral system evolving in Indonesia today is rooted in the opening of political opportunity structures, bolstered by social mobility, economic growth and broader participation in education and politics. The driving force behind this phenomenon is the middle class. Particularly in the provincial towns, its members have become active negotiators between the global and the local, and between the cosmopolitan centre and the hinterland. In their attempts to boost their identity and social status, the middle class is at the forefront of calls for the compatibility between Islam and modern values such as democracy, tolerance and human rights. They play a significant role in the way Islamization and democratization are interacting in Indonesia.

This chapter analyses the changing role of Islam in Indonesian provincial towns, as a new middle class is becoming more aware of the importance of religious identity for their social status and lifestyle. Focusing on developments in two medium-sized towns - Kebumen in Central Java and Martapura in South Kalimantan - it aims to show how two major transformations shaping contemporary Indonesia - democratization and globalization - are generating a public sphere in which politics and religion are subtly intertwined. Mass education and mass communications have facilitated an awareness in Muslims of the need to reconfigure the nature of religious thought and action, create new forms of public space, and

\footnotetext{
* An earlier version of this chapter appeared in Hasan 2011.
} 
encourage debate over meaning. Within this context Islam has become the subject of dialogue and civil debate. Open contests over the use of the symbolic language of Islam and its meanings have increasingly shaped this new sense of public space that is discursive, performative and participative. The appearance of 'public Islam' in the Muslim world has coincided with the emergence of a new middle class which involves itself in the debates about objectifying Islam. This class is mainly distinguished by the capacity of its individuals and households to accrue surplus income, beyond that needed for the necessities of life. Their rising demands for a more nuanced lifestyle urged them to adopt Islamic symbols as a mode of modern cultural expression in public spaces. Islamic symbols provide a sense of legitimacy and moral value for members of the new middle class, and a means by which its members' social identities are formed.

The trend for the metropolitan urban middle class to adopt Islamic symbols to claim distinction and moral legitimacy for their consumptive lifestyle has resonated through Indonesian Islam, and profoundly impacted the dynamics also in provincial towns. Due to the development of massive infrastructure and the advancement of mass communications, the boundaries of big cities and provincial ones have become increasingly blurred. Any trends that are developing in the big cities can easily progress to provincial ones. But they are not just copied. This chapter aims to show the particular way in which 'public Islam' has been appropriated in provincial towns. The process of appropriation also involves agency, shaping the form of Islam that will prevail in the provincial town's public spaces. The growing middle class is facilitating the burgeoning of a new form of market-friendly piety, which accepts the idioms of modern democracy. At the same time, this market-friendly piety needs to be legitimized by showing a continuity with local history and culture. Institutional symbols of traditional religion often resurface and require affirmation from religious actors who, in turn, have sought sources of legitimacy in their effort to offer Islam in provincial public spaces. This chapter thus examines the way in which the middle class plays a pivotal role as an agency facilitating the growth of public Islam in provincial Indonesia where ideas about locality, tradition, modernization and globalization, as well as ideas about Islam's significance for urban public life, are mutually reinforcing.

\section{Islamization in Provincial Indonesia}

In a country like Indonesia, in political, economic, cultural and administrative matters, towns play an intermediary role between the cosmopolitan centres and the hinterland. They serve as a meeting point and mediator 
between the outward-reaching national (and global) culture, institutions and processes, and the increasingly self-assertive agricultural village majority. Unlike the cosmopolitan centres, where there is greater sociocultural differentiation, a tension between the global and the local is often more explicit in smaller towns, where it is held more in check by crosscutting personal ties. The global is spread through modern political, educational, economic and cultural institutions. Its legitimacy, however, is bolstered by means of the appropriation of key concepts associated with tradition and local culture. Looking at Indonesia from the vantage point of the provincial town allows us to understand how the local, the cosmopolitan and the global have intertwined in informing multiple manifestations of the complex relationship between the political, the economic, the social, the cultural and the religious.

This is not ungrounded theory. Provincial towns seek to manage tension between the global and the local by means of appropriation and harmonization, to some extent. This phenomenon is evident in Kebumen, the market and administrative centre for a district bearing the same name, located in the southern part of Central Java. This town has vast hectares of lush paddy fields that yield around 150,000 tonnes of rice per year. Ironically, based on the data on 'recipients of direct cash assistance' (penerima bantuan langsung tunai, or penerima BLT), in 2007, $46 \%$ of Kebumen's population still lived in poverty. When I carried out research for this chapter in 2007-2008, Kebumen was led by district head (Bupati) Rustriningsih and her deputy, Nashiruddin al-Mansur. It was recorded as the fourth poorest district (kabupaten) of the 35 districts and cities of Central Java. In addition, more than 17,000 people were recorded as illiterate, and 13,957 children aged between 7 and 15 years were not enrolled in school. The school drop-out rate was also very high. It was reported that more than 66,00o people had not completed their primary education. The high numbers of illiterates and school dropouts explain why 96,024 families in Kebumen (or 30.43\%) are classified as poor or 'pre-prosperous' (prasejahtera) and $75,05^{2}$ families $(23.78 \%$ ) are in the slightly higher socio-economic status group 'prosperous 1' (sejahtera 1). More shocking still, 35,311 people, from a total of 315,591 people in the productive age group, were unemployed. The high unemployment rate is correlated with the fact that a huge number of Kebumen workers have migrated for greener pastures abroad (Bappeda Kabupaten Kebumen 2006).

Despite its claimed status as a santri town (kota santri) with $99 \%$ of its population being Muslim, Kebumen had never strongly supported Islamic parties. No Islamic party had won a majority since the first elections in 
1955. However, kyai, traditional religious scholars known as ulama in Java, do have an important cultural influence in Kebumen. The latest data show that the district has 121 pesantren, traditional Islamic boarding schools led by kyai. These religious leaders have long held a special position in the Kebumen community, as reported by the sociologist Jennifer Alexander during her observations in the 1980 . Her research primarily examined economic development, and took place in a district located to the east of Kebumen. She concluded that Clifford Geertz's characterization of Javanese society as being divided into santri, abangan and priyayi groups was not relevant in Kebumen. Geertz's santri group practised orthodox Islam, while the abangan population practised a more syncretic, Javanese-flavoured version. The priyayi were drawn from the traditional Javanese aristrocratic class, and often held responsible administrative positions. According to Alexander, in Kebumen people tended to reject the santri/abangan distinction and the trichotomy santri/abangan/priyayi. They generally pictured themselves as Muslims with a firm commitment to Indonesian nationalism (Alexander 1987:16). Unlike other orthodox santri, who stress the formalization of religious expression and the pursuit of piety and orthopraxy, the majority of the population Alexander described were able to strike a compromise between Islam, traditional values and indigenous culture.

Kebumen is probably better pictured as a place where Islamic-Javanese moderate practices prevail and abangan beliefs are still alive. The military has described several isolated districts in Kebumen as 'red spots', once under the domination of Communist influences. Kebumen has also been described as a 'tinderbox', or a place where both the political extreme left and extreme right could be found. In $195^{\circ}$ a religious rebellion exploded in Kebumen as a consequence of rationalization within the body of the Indonesian Republic Armed Forces. This rebellion was led by a local militant leader, Machfudz Abdurrahman, the owner of the Al-Kahfi Islamic boarding school in Sumolangu and more popularly known as Kyai Sumolangu. He refused to merge with the 'Lemah Abang Battalion' formed by the army. Instead, he formed his own battalion, known as the Chimayatul Islam. Unfortunately negotiations between the kyai and the army ended in disagreement, and as a result a confrontation with the army was inevitable. ${ }^{1}$ Given this historical peculiarity, the

\footnotetext{
1 Several scholars believe that the Angkatan Umat Islam (AUI, Islamic Congregation Force), a rebellious movement in Kebumen in the early 1950s, had connections with the wider regional rebellion of that era led by S.M. Kartosuwiryo and known as Darul Islam/ Tentara Islam Indonesia (DI/TII, House of Islam/ Indonesian Islamic Army) (Singgih Tri Sulistiyono 2000).
} 
highest political position in Kebumen was always reserved for army officials.

Only recently have Islamic forces and secular power reached a point of convergence in Kebumen. A huge billboard in front of the regent's official residence on Kebumen's main square shows Rustriningsih wearing a trendy colourful headscarf. This was a new - for years she had been bareheaded in public. Her (male) deputy Nashiruddin wears a green turban. Islamic symbols have replaced Javanese insignia as the tools of political communication. Islamic nuances are being strikingly incorporated into the bureaucratic sphere elsewhere as well. As is occurring at the national level, more and more female civil servants in Kebumen are wearing headscarves and becoming involved in regular religious activities organized by the region's government units. Arabic maxims promoting efficiency and transparency are scattered around the walls of local-government offices. The increasingly conspicuous religious symbols in Kebumen's public places reflect the sustained penetration of Islamic orthodoxy into the heart of this abangan culture, and its attempts to move towards full integration as part of a modern, globalizing Indonesia.

As in other mid-sized Javanese towns, Islamic proselytizing (dakwah) groups have grown more active in Kebumen over the years. Young people are at their core. Their goal is to formalize religious expressions and introduce a more orthodox version of Islam into Kebumen society. Notable among them are the Hidayatullah group, which is under the auspices of the Al-Iman Foundation, and the PKS, which coordinates the Ibnu Abbas, the Perempuan Muslimah and the Iqra Club Foundation. Both groups set up educational institutions and introduced what they call integrated Islamic schools, in which the younger generation of Muslims are taught to internalize the principle of Islam's totality. These schools are founded on the belief that the future of Indonesia lies in the commitment of Muslim youth to consistently follow the example of the Prophet Muhammad and the first generation of Muslims (Salaf al-Salih - pious ancestors). ${ }^{2}$ One impact (among many) of the dakwah activities organized by the Iqra Club is that $90 \%$ of female students at SMU 1 and SMK 1 , Kebumen's popularly preferred senior high schools, now wear headscarves.

The penetration of the new dakwah groups was not totally unexpected. Mainstream Muslim groups, such as Nahdatul Ulama and Muhammadiyah, had long expressed concern about the weak religiosity and domination of

\footnotetext{
2 Interviews with the chairman of the Al-Iman Foundation, Muhammad Yunus, and with the headmaster of SDIT Al-Madinah, Abdullah Munir. Kebumen, 17 October 2007.
} 
abangan culture in isolated villages in several of Kebumen's sub-districts, such as Sempor, Buayan, Karangsambung and Mirit. Although many ulama and religious teachers were aware that the new ultra-orthodox dakwah groups might challenge their established religious practices and give new expression to their faith, they generally welcomed them as partners in the struggle for the glorification of Islam (syiar Islam) throughout Kebumen. They even acknowledged the creativity of the way they packaged Islam to make it more attractive to the broad Kebumen (or, more precisely, abangan) community. ${ }^{3}$ Fear of the way these new dakwah groups have expanded has only recently surfaced as a public concern. The catalyst was their systematic campaign to infiltrate schools, many of which belonged to Muhammadiyah, to recruit Muhammadiyah youths into their cause. A number of the Muhammadiyah faithful openly challenged the expansion of puritan dakwah into their educational institutions, in Kebumen town itself as well as in its sub-districts of Gombong, Kutowinangun, Sadang, Pejagoan and Karanganyar. ${ }^{4}$

The growth of Islam's public visibility can also be seen strikingly in Martapura, the capital town of Banjar district, which is located $40 \mathrm{~km}$ to the north of Banjarmasin, the capital city of South Kalimantan province. This district is divided into 17 sub-districts with 288 towns and villages. Since its establishment in 1950, the Banjar district's head has changed 16 times. The current district head is Khairul Shaleh, and his running mate is Muhammad Hatim Salman. According to 2006 statistical data, the total population was 464,148 people, comprising 238,162 men and 225,986 women. The most densely populated area was the district capital, Martapura, with 2,042 people per square kilometre. School participation has risen over time, with increases in the number of schools. Currently there are $35^{\circ}$ primary schools, 39 junior high schools and 9 senior high schools under the auspices of the National Department of Education. The total number of students is 55,269 . In addition to this, there are 217 schools at all levels under the Department of Religious Affairs, with 26,872 students. There are 459,124 Muslims, compared to 314 Protestants, 209 Catholics, 101 Hindus, and 98 Buddhists and others. Based on the same statistical data, there were 2,118 job applicants in 2006, many of whom

\footnotetext{
3 Interview with Bambang Purwanto, Islamic teacher and staff at the Regional Department of Religious Affairs in Kebumen, Kebumen, 16 October 2007.

4 Interview with Muhammad Dahsyad, a member of the education council of Muhammadiyah in Kebumen, and Muhammad Abduh Hisyam, the secretary of Muhammadiyah in Kebumen, 12 October 2007.
} 
held senior-high-school diplomas. From this number, 1,136 were reportedly absorbed in various job markets and positions (Bappeda Kabupaten Banjar 2006). ${ }^{5}$

Close identification of Martapura with Islam can be traced through its historical trajectory as the capital city of the Banjar Sultanate before the Dutch ruined it in the war of 1859-1863. There, ulama played a pivotal role in politics. Muhammad Arshad al-Banjari, a charismatic ulama in the nineteenth century, was the first grand mufti of the Banjar Sultanate, under Sultan Adam's rule between 1825 and 1857. As grand mufti he integrated the shariah into the political structure of the Banjar Sultanate, and was responsible for issuing the Sultan Adam Law (Undang-Undang Sultan Adam) stipulating application of various aspects of the shariah, especially the ritual (ibadah) and the social contract (muamalat), in accordance with Shafiite legal doctrines. This historical trajectory explains the identity of Martapura as a town that prides itself on being the 'front porch of Mecca' in Kalimantan (Ariffin 2004:33-5). In addition, close identification of Martapura with Islam has much to do with the self-image of the Martapuran Muslims, who portray themselves as a pious, pleasant and polite society, thus differing from the other Banjarese clan groups, especially from the Upper River (Hulu Sungai).

The presence of Islamic symbols in the town's public space became noticeable during Abdul Madjid's leadership of the Banjar district in the mid-199os. The Light of the Saved Earth (Cahaya Bumi Selamat, or CBS) was built on the site of the town square, which had long provided a community space for Martapuran society. CBS is a jewellery trading centre. The vast building is in the architectural style of the Middle East, and at its centre a huge monument stands tall, complete with beautiful Arabic calligraphy. The overall effect is that of a magnificent, stunningly beautiful palace. It is a prestigious project intended to enhance the image of Martapura as a town built on the trade in jewellery, as well as the front porch of Mecca. The image of Middle Eastern architecture dominating the Martapura townscape clearly illustrates the deeply penetrative forces of Islam. During Abdul Madjid's leadership, the Sekumpul Religious Study Group emerged and rapidly grew to become a religious, political, economic and social magnet for Martapuran society and Muslims in South Kalimantan in general. This study group was founded in the early 199os by

\footnotetext{
5 Interview with Ahmad Rabbani, staff at the Regional Development Planning Board of the Banjar district. See also the annual report by the Regional Development Planning Board of Banjar (Bappeda Kabupaten Banjar 2006).
} 
Zaini Gani, better known as Guru Zaini, a charismatic cleric who then decided to move from his old residence in Keraton sub-district to live in Sekumpul. At that time Sekumpul was a quiet, desolate area, full of karamunting trees. The presence of Sekumpul is emblematic of the growing importance of Islam in Martapura's public sphere. As a provincial town located outside of Java, which sees itself as marginalized in the highly centralized process of national development, Martapura has drawn strength from Islamic symbols to reinforce its local identity and, thereby, negotiate its position in the face of the central government.

\section{Middle Class and Lifestyle}

Earlier debates on Indonesia's middle class paid scant attention to Muslim groups, while recognizing their existence as one of the drivers of change, together with the entrepreneurial and professional intermediate groups and the officer corps. However, given the antagonistic relations between Suharto's New Order and Islam, Muslim groups tended to be excluded from the circles privileged to benefit from this change. Those circles did include entrepreneurs, professionals and military political managers, who shared a common interest not only in preserving their acquired comfort and status, but also in restraining Islamic political claims (Lev 1990). ${ }^{6}$ Historically speaking, Islamic political forces had long been the main opponent of the bureaucracy, standing on the front line to challenge secular power (Samson 1972; Kuntowijoyo 1990).

The failure to make Islam a formal part of the state system served as a catalyst for the emergence of a Muslim middle class, centred around professionals, civil servants, intellectuals and military officers (Wahid 1990:22-4). They came from santri-priyayi families, in the Geertzian paradigm, who sent their sons and daughters to modern schools and through this route propelled them into various economic and bureaucratic sectors to become professionals in both state and private companies, expert staff assisting the ministers, members of parliament, directors general, heads of sub-directorates and many other strategic positions. This process of

${ }^{6}$ Lev's analysis received a critical remark from William Liddle, who saw growing interests among the middle class to trade their independence for a larger share of the benefits of state largesse. Liddle had in mind the larger, modern, urban business entrepreneurs and professionals, as well as rural lower middle classes such as rich rice farmers, producers of various agricultural commodities and even some devout Muslims (Liddle 1990). 
embourgeoisement or priyayization in Aswab Mahasin's term, led the santri professionals to see Islam no longer as an alternative to the existing system, but rather as the inspirational base for a national, democratic framework for society (Mahasin 1990). The inclusion of santri in the bureaucracy and civil services in turn contributed to the New Order's marked shift toward accommodating Islam in politics, shown by Suharto's personal support for the establishment of the Association of Indonesian Muslim Intellectuals (Ikatan Cendekiawan Muslim Indonesia, or ICMI) in 1990. As a consequence of these changes in Indonesia's political environment, Muslim political groups have increasingly become the main patrons of the state, complete with a 'greening' process in the House of Representatives and the cabinet. From within the state system the Muslim middle class struggled to give Islam a central role in politics by repudiating the goal of an Islamic state, mobilizing ecumenical religious support, promoting women's rights and championing Islam-based democratic ideals (Budiman 1994; Anwar 1995).

Fluctuations in Islam's political relationship with the state inform both the dynamics and the formation of an Indonesian middle class vis-à-vis the state, and this makes it difficult to identify the main characteristics of the class from a purely political perspective. The 'cultural capital' held by the middle class provides a foundation for the emergence of civil society associated with demands for representative space in political institutions. However, the middle class also has an interest in maintaining law and order, political stability and material prosperity, and this may lead to their support for authoritarianism (Rodan 1996; Heryanto 1996; Saravanamuttu 2001). Beyond political parameters, one can identify the Indonesian middle class by its performance in the public sphere and its consumer-based lifestyle. Howard Dick reminded us of the importance of the mode of consumption as a defining characteristic of the Indonesian middle class (Dick 1985, 1990). This argument seems plausible, since the 'mode of consumption' can be seen not only as a cultural representation of a class, but also as a political statement. Consumption practices, though overwhelmingly apolitical in intent, have significant political consequences (Young 1999:57). To a large part the mode of consumption and lifestyle of the educated urban middle class inspired the image of modern Indonesia promoted on the nation's television screens and through government broadcasts, and exemplified by the nation's leaders. The growth of the urban middle class itself is paralleled by the increasing popular acceptance of consumer patterns associated with modernization (Guinness 1994:285-6). 
A sense of personalized Muslimhood has developed out of this context, which allows the middle class to demonstrate their religious identity through bodily, purchased practices and goods (J. White 2005; Bayat 2007). This model of Muslimhood is indubitably associated with their attempts to construct new narratives of themselves and their place in the world from creative blends of their own cultural inheritance and global influences (Heryanto 1999). In the words of Göle, the Muslimhood model has enabled Muslims to experience the 'banalization process'. Actors from diverse backgrounds are involved in shaping the face of Islam in the public space and entering into the modern urban space with little hesitation. By using global communication networks they participate in public debates, track patterns of consumption and study the rules of the market, while at the same time embracing individualistic, professional and consumerist values (Göle 2006).

Seen from this perspective, Islamic symbols seem significant to class mobility and the formation of the new middle class. In contrast to the old bourgeoisie, the new middle class, according to Bourdieu, no longer prioritizes the ascetic ethic of production and accumulation, but favours a morality of consumption based on credit, spending and enjoyment. This is in line with his understanding about power as culturally and symbolically created, and constantly re-legitimized through an interplay of agency and structure. The main way this happens is through what he calls 'habitus', which is associated with the way in which actors calculate and determine future actions based on existing norms, rules and values representing existing conditions. In Bourdieu's words, the term habitus refers to '[s]ystems of durable, transposable dispositions, structured structures predisposed to function as structuring structures, that is, as principles which generate and organize practices and representations that can be objectively adapted to their outcomes without presupposing a conscious aiming at ends or an express mastery of the operations necessary in order to attain them' (Bourdieu 1977:72). Within this context Bourdieu sees social class as something not defined solely by a position in the relations of production, but by the habitus which is normally associated with that position (Navarro 2006).

The work of Bourdieu provides a useful conceptual framework for understanding the new Muslim middle class's choice of Islamic symbols as the way to encourage the reproduction of privileges. They live in a social world driven by a new economy which judges people by their capacity for consumption, their standard of living and their lifestyle, as much as 
by their capacity for production. Bourdieu's scheme indeed associates the new middle class with symbolic consumption and post-modernity (Bourdieu 1984:310). This allows us to investigate the new middle class's conception of lifestyle in relation to its habitus, and its concern to expand and legitimate its own particular dispositions and way of life. The nexus between habitus, consumption and lifestyle proposed by Bourdieu is central to the new middle class's strengthening of its symbolic capital by promoting cultural forms other than those enshrined in traditional middle-class virtues, and thus to its struggle with the traditional middle class (Featherstone 1987:158). To be sure, in Bourdieu's quite distinct definition of class, cultural factors are seen to operate alongside economic ones.

As a matter of fact, the rising consciousness among the new Muslim middle class of the importance of Islamic symbols, with its willingness to engage in debate and objectify religion, looked to the availability of religious space within the urban landscape of big cities. In view of the growing demands for such space, governmental and business offices built mosques and musalla, small places to pray. Elite housing complexes and shopping centres provided meeting places for listening to public lectures on Islam (majelis taklim). Convention centres and five-star hotels advertised venues for religious programmes and Islamic study packages. Luxury Islamic centres, with a large mosque as the main building surrounded by training and educational buildings, shops and a hotel, have been built on large tracts of land in major cities like Jakarta, Surabaya and Makassar. The new Muslim middle class comes to these places to engage in reciting the Qur'an, chanting $d h i k r$ (the profession of the faith), and the like, while discussing various aspects of Islam. In this way Indonesian Islam has experienced a process of gentrification, favouring global high-technology and consumerist Islamic appetites (Abaza 2004). While dakwah has somehow become urbanized, new creative agents and young, popular preachers have emerged to work in both public and private settings. They offer a variety of innovative dakwah programmes in the interests of the new middle class.

The backdrop of this phenomenon was the Islamic revival that has swept across Indonesia since the 1980s. This had a profound effect on the urban middle classes' rising demands for Islamic symbols as a mode of modern cultural expression in public spaces (Hasbullah 2000). Islamic symbols reflect middle-class attempts to construct new narratives of themselves and their place in the world through practices of distinction. 
The distinctions made in different areas of everyday life are drawn from history, memory, friendship, consumption and recreational practices. Their inspirations come from multiple sources. The symbols themselves are subject to negotiation within the habitus of the class. In this way Islam has been transformed into a symbol of modernism and even elitism, and become part of a lifestyle. For instance the baju kurung (traditional modest attire of women) and mini telekung (outermost robe worn by women when praying), increasingly popular among Malaysia's Muslim middle class, are imbued with Islamic religiosity, whilst modesty, discipline and control are upheld. There is some experimentation here, symbolized by the exploration of mobility and gender identity of middle-class Malay society. Being most forcefully subjected to intensified Islamic requirements, women developed 'a strategic knowledge of dressing as a particular form of Islamic consumption, situated between public display of class and covering the body' (Fischer 2008:78-9).

A similar pattern of social differentiation is evident among the middle class in Martapura. Over time the fascination with Guru Zaini and the Sekumpul teaching complex drove thousands of middle-class people from Martapura town and other South Kalimantan cities to migrate to the Sekumpul area (Alhakim 2006). They built their own homes around the seven houses owned by Guru Zaini and his relatives, in the same row as the Al-Raudhah, the 'Kompleks Dalam Regol' (Complex in the Archway). The Sekumpul complex inspired the Martapuran community to the cultivation of culture and social refinement. Trends made popular by the followers of the Sekumpul religious study group have a wide influence throughout Martapura and other towns in South Kalimantan. For instance, the trend for men to wear the koko shirt and the white kopiah (a kind of rimless cap), and for long dresses and colourful jilbab for women, originated at Sekumpul, and this way of dressing is now very popular in South Kalimantan. Sekumpul's role as a lifestyle trendsetter for South Kalimantan's provincial cities has evolved naturally.

Owning a luxurious home in Sekumpul automatically privileges a person as part of the Sekumpul community. This community is very close, thanks to Sekumpul's TV, which features religious programmes from the Dalam Regol. The TVhelped everybody living in these houses to strengthen their communal feeling as members of Sekumpul society. These houses are alive with activity for four days of the week, particularly on Friday afternoons when people gather to follow the religious activities held in the Al-Raudhah. After this, most people return to their respective towns and their daily routines as entrepreneurs, traders, civil servants, and so 
forth, leaving only caretakers in their Sekumpul houses. Some people stay permanently in Sekumpul, and partly due to Sekumpul some of them have been fortunate enough to develop massive business networks, expanding the market for their products throughout southern Kalimantan. People like Sarkani, Norhid and Abdullah Assegaf have become successful businessmen in coal mining, the traditional Banjarese batik industry (sasirangan), precious stones and jewels, and other large-scale enterprises in South Kalimantan (Alfisyah 2005). Ismail Morsade is another succesful businessman living in Sekumpul. He was originally a Madurese entrepreneur from Sampit, Central Kalimantan, who decided to migrate to Sekumpul during the bloody ethno-religious Madurese/Dayak conflict of the late 199os. ${ }^{7}$ For Morsade, Sekumpul is not only a place to enjoy the overwhelming atmosphere of Islamic spirituality associated with Guru Zaini, who helped him to overcome the emotional trauma of the conflict. It also offers him socio-political-religious protection, and a promising arena to develop his business activities in South Kalimantan. ${ }^{8}$

The religious appeal of Sekumpul has made the community prosperous. Gradually, through its complex role at the intersection of multifaceted religio-political and economic activities, Sekumpul has come to be seen as the 'kampung urang sugih' (village of the affluent) of South Kalimantan. As a spiritual market, Sekumpul is more than just a site for religious ceremonies and rituals; it has become a new source of religious and moral guidance. More importantly, it has become a medium for religious middle-class consumers in South Kalimantan's towns to seek a new identity and personal meaning - by consuming. At Sekumpul they can enjoy a spiritual uplifting by Guru Zaini, but after that they can shop for all the accessories and gadgets associated with Sekumpul. Most people do not hesitate to spend millions of rupiah for an exclusive Mushab Al-Qur'an (Qur'anic edition) signed by Guru Zaini, a tasbih fuqah (a type of rosary) or a Sekumpul-stamped rihal jati (a small teak table to put the Qur'an on). Even more collectors buy the jilbab and kopiah haji sold in Sekumpul. ${ }^{9}$ Slowly, Sekumpul has evolved its own unique brand identity, sought after by its own middle-class market segment of loyal customers.

\footnotetext{
7 For a further account of ethno-religious conflicts in Sampit and other provincial towns during the late 1990s, see Van Klinken 2007.

8 Interview with Ismail Morsade, Martapura, 2o February 2008.

9 Interviews with Nafsiah, a religious figure who resides in the Sekumpul neighbourhood, 11 February 2008, and with Dede Hidayatullah, a civil servant who also resides in Sekumpul, 22 February 2008.
} 
Possessing Sekumpul merchandise and accessories allows a person to undeniably claim membership of Sekumpul's middle-class community.

\section{Commodification}

The growing interest of the new middle class in the current wave of market-friendly Islam has spread to a large and diverse segment of Indonesian Muslims, and this means expanding market opportunities for products related to these activities. It is only logical that increased demand for the latest models for innovative religious expression has led Indonesian fashion designers, the garment industry and other business players to launch new products. Again, the middle class plays a pivotal role, not only as loyal consumers but also as commercial agents providing affordable 'Islamic' products that follow (or even set) the latest fashion trends. They distribute their products widely to reach even remote parts of the countryside. Religious commodification should not be confused with commercialization. It is not a phenomenon that exists solely to make money. Religious commodification entails ideologization of commodities and commoditization of religion; it is as much about selling ideology as about selling products (Lukens-Bull 2008). Religious commodification has in fact very much to do with the way religion, in this case Islam, is packaged and offered to a broader audience, and how this has produced a framework for the moral order of society through the objectification and systematization of Islamic values and practices as a normative model.

Middle-class entrepreneurs are at the forefront to transform Islam into a symbolic commodity relevant to an entire social class based on demands for lifestyle, modesty and enjoyment, and no longer simply as a set of rituals, beliefs and doctrines. Sociological debate about this phenomenon conceptualizes consumption in the modern age as one of the most crucial, defining class experiences, and an expression of identity and representation of the self. Since religion has emerged as a symbol of elitism associated with the road to success, statements of one's personal identity can involve the use and consumption of religious symbols, as can be seen in the Indonesian public sphere friendly to Islam. In the hands of middleclass entrepreneurs, the symbols of faith have thus become commodified as markers of social status. Miller suggested that commodifying religion has reduced religious beliefs, symbols and values into free-floating signifiers to be consumed like anything else (Miller 2004). As such, it takes them from their original contexts and throws them into a cultural 
marketplace where they can be superficially embraced without being actually put into practice.

The heart of the commodification process is found in places such as the sprawling Tanah Abang market in metropolitan Jakarta, where countless tightly packed stalls are festooned with products from small- to middlescale industries. These industries also operate in provincial towns such as Tasikmalaya, Pekalongan and Solo. They not only meet market demands, but also set market trends nationally. This reciprocal relationship is driven by business acumen rather than religious motivation. 'Islamic industry' thrives in parallel with the emergence of upwardly mobile consumers, who seek models of behaviour appropriate to their newly elevated status. But the end result is co-determined by those on the economic margins who 'show a fascination with the cultural codes associated with the wealth and power of the new elites' (Young 1990:57).

The sprouting of Islamic symbols in Indonesian provincial towns coincides with middle-class success in expanding their businesses. In Kebumen, many of them have been able to open stores along Sutoyo, Kolopaking and Kusuma streets, selling mobile phones, electronic gadgets, ready-made garments and much more. Market competition has been enlivened by the entry of new players, kyai or young figures who are closely affiliated with the biggest Islamic organizations in Kebumen, namely Nahdatul Ulama (NU) and Muhammadiyah. One of them, Wahib Machfudz, owns a number of stores under the label Al-Huda, the same name as his pesantren, selling books, clothing and electronic accessories, as well as several telephone shops. Another successful businessman, Cholidi Ibhar, is a former local parliamentarian from the religiously coloured PKB (Party of Nation Awakening) in Kebumen. He specializes in selling Muslim fashion under his own label Amanah, in competition with similar shops such as Tadzkiya, Zahra, Mangga Dua, Tiara 27, and Asri. As well as these retailers, several young NU and Muhammadiyah activists, such as Slamet Faisol and Muhammad Dahsyad, have become wholesale clothing-supply agents to small retail stores throughout Kebumen. Other prominent business players from a santri background have arisen in Kebumen to creatively broaden the market coverage of local commodities. Among them are Yahya Mustafa, Ibnu Ashari, Mastur Soba'i Aziz, Ayub, and Slamet Faisol. Yahya Mustafa has become the most prominent of them all by expanding basket-weaving craftwork for export. He won the (bank) Danamon Award for his hard work. Another success story is that of Ibnu Ashari, now the owner of the Sriti plastic-cutting factory located in 
Kelurahan Watubarut, Kebumen. This entrepreneur has an NU background, and was once active in the NU organizations Ansor and Garda Bangsa Kebumen (2002-2007). He opened his own factory after working for ten years in the Naga Semut plastic factory, owned by the Chinese entrepreneur Tan Han Jian. ${ }^{10}$

The establishment of the Centre of Muslim Economy (Sentral Ekonomi Muslim, SEM), in Sutoyo Street near the Tumenggungan traditional market, is emblematic of the emerging middle-class enterpreneurs in Kebumen, who have witnessed a marked shift in class formation. In 2004, SEM was built on land donated to the Darussalam Mosque, situated in Kebumen sub-district. In cooperation with an investor, 68 kiosks were built, but unfortunately not more than 10 kiosks in the front row were able to stay in business. The remaining kiosks were closed, or never even opened. A lot of effort has gone into invigorating this market, mostly to settle the debts of the wholesalers who invested $\mathrm{Rp} 1.2$ billion for construction of the kiosks. ${ }^{11}$ Initially SEM was to be a convenient shopping centre where the emerging middle class in Kebumen could spend their money and meet their growing need for 'Islamic' clothing and accessories, thus strengthening their class distinction. However since it was not modelled after luxurious shopping malls in Yogyakarta and other cities in Central Java, SEM never evolved into an important shopping centre bringing pride to Kebumen society. This fact indicates that marketing Islamic commodities by itself is not enough - they need to be marketed in the modern way, and not through kiosks in a traditional market.

In the middle of SEM's failure, the Jadi Baru Mall (JB) was built, despite opposition from the traditional traders and Chinese businessmen of Kebumen. JB belongs to a supermarket network centred in Kroya, Cilacap. It was built by an entrepreneur from Cilacap, Mahasin, the besan (relationship between parents whose children are married to each other) of an influential cleric, Gus Anam, from Leler Banyumas. The construction of JB was supported by local Kebumen entrepreneurs. One of them, Yazid Machfudz, is the brother of Wahib Machfudz, the chairman of the consultative council of Kebumen's NU branch and a businessman. There has long been a tight bond between Mahasin and Yazid. Yazid was convinced that the development of JB would bring prosperity to the Muslim community, because the owner is a member of NU and the mall would improve Kebumen's economy by attracting new people and new life to a part of

\footnotetext{
10 Interview with Ibnu Ashari, 14 January 2008.

${ }^{11}$ Interview with Nurhadi, member of the Nadzir Darussalam Mosque, 17 March 2008.
} 
town that was at the time deserted. ${ }^{12} \mathrm{JB}$ would have a special section for Muslim women's wear, complete with all the accessories and gadgets needed by women who wanted to appear 'Islamic' yet modern.

The middle-class ability to expand their business network by selling 'Islamic' products is also evident in Martapura. Realizing Sekumpul's market value, Guru Zaini launched Al-Zahra Productions, a brand name for the numerous merchandise, accessories and gadgets associated with Sekumpul. The core products of Al-Zahra are Muslim fashion, prayer/ ritual attire and accessories, with its production lines located in Tasikmalaya and Surabaya. Al-Zahra later expanded its production line with the opening of the Ar-Ruhama bookstore and Ar-Raudhah publications. Both of these businesses were put under independent management, and Guru Zaini focused on Al-Zahra. Besides the ritual merchandise shops and Muslim women's fashions under the umbrella of Gallery Al-Zahra, Al Zahra now has business lines such as Al-Zahra Fast Food, imitating the model of California Fried Chicken, AZ Bakery and Al-Zahra Supermarket. Al-Zahra also produces its own mineral water, branded simply as 'Sekumpul'.

Al-Zahra claims the source of its business inspiration was Aa Gym's Management Qalbu Company, but with Guru Zaini as a marketing figure to target certain market segments, particularly in the provincial towns of South Kalimantan. Al-Zahra's major selling point was the fact that it was owned by Sekumpul, and it grew dramatically. Even after the death of Guru Zaini in 2005, Al-Zahra still stands strong. Its consumers are the thousands of visitors coming to Sekumpul every day. Although the popularity of Sekumpul as a centre of ritual seems to have faded slightly, Martapura still remains a religious and social magnet for the provincial towns of South Kalimantan, and the Sekumpul business enterprises continue to expand. The expansion has been backed by many succesful enterpreneurs, including Sarkani, Norhid, Assegaf and Morsade. The enterpreneurs have developed various 'Islamic'-type business enterprises of their own, inspired by Sekumpul. ${ }^{13}$ For instance, a real estate company owned by Morsade has developed exclusive 'Islamic' residences in Banjarbaru, near Martapura, named the Ismor Housing Complex after the abbreviation of his name. ${ }^{14}$

12 Interview with Yazid Machfudz, 7 November 2007.

13 Interview with Ridwan, Former Director Al Zahra, 17 February 2008, and Rizki Wijayakusuma, Ahmad Diauddin and Suriani, admin staff of Al-Zahra, 19 February 2008.

14 Interview with Ismail Morsade, Martapura, 20 January 2008. 
What we have seen here is the prominent role of the new middle class as an agency to facilitate the process of religious commodification. Agency here specifically refers to the capacity to realize Muslim interests against the dominant ideology that makes it difficult to reconcile piety and other forms of public religious expression with modernity (Giddens 1984, 1987). An active engagement in the construction of religious debate and discourse in the public space primarily characterizes this particular type of agency, through which a new form of interpretation and meaning is offered for religious expression and identity. Inherent in its efforts is a criticism of the hitherto hegemonic religious-establishment discourse and its traditionalism and passivity. In contrast to Saba Mahmood's (2005) understanding of agency in the case of a mosque women's movement in Egypt as centred on individual intentions to engage in self-transformation through passivity and feminine docility, no longer solely through the lens of subversion, agency in this Indonesian context involves the process of social transformation and strategic choices. ${ }^{15}$ Instead of giving up religiosity, considered as a source of backwardness, it liberalizes religion from its traditionally subservient, passive and docile posture by turning it into a source of moral legitimacy and distinction to represent a modern form of life.

The fact that the growing trend for women in Indonesian provincial towns to wear headscarves is tied to the larger process of social change sheds some lights on the importance of agency in the process of negotiation between tradition and modernity. As Suzanne Brenner (1996) observed, the practice of veiling among women in Java represents both a new historical consciousness and a transformation of self that challenges local tradition as well as Western models of modernity. Veiling is thus perceived as an active process to produce a vision of a society that is distancing itself from the past as it embarks upon a new modernity. Indeed, veiling allows middle-class women in Java to live away from home and move into predominantly male social, political and economic spaces with a heightened commitment to the profession of Islam (Smith-Hefner 2007; Hamdani 2007). In fact, the headscarf helped Rustriningsih, the then Kebumen district head, to secure her position as the first woman to hold the highest political position in Kebumen. As well as her pioneering efforts to improve transparency and good governance in Kebumen, Rustriningsih's politics of veiling played a significant role in her success in winning support from the majority of the Kebumen society. No less

15 For critiques of Mahmood's theory, see Haniffa 2008 and Jasani 2008. 
significant, Rustriningsih's veiled performance became a style reference and established a dress code for many politicians, religious leaders and other members of the middle class in Kebumen. ${ }^{16}$ Once Islamic attire was adopted by Kebumen's elite and middle class, the koko shirt and the trendy jilbab became popular throughout Kebumen.

\section{Islam in Local Politics}

Because of Islam's complex relationship with tradition, locality, modernity as well as globalization, it is hard to determine whether Indonesia has actually reached the brink of a post-Islamist turning point. Such a point could be signalled by a shift in the pattern of Islamic activism from revolutionary collective activism towards an individual activism which accepts the imperatives of modern life. If the first is shaped by ideologies, what Bayat calls 'post-Islamism' distances itself from political nuances and collective militancy, whilst still ensuring harmonization and parallelism between Islam and modernity (Bayat 2007:10-11). No doubt, the reality of an electoral democratic system that guarantees much broader public participation in politics, although this participation may lack depth, serves as a catalyst for the burgeoning of public Islam. It is a concept that refers to the appearance of an 'Islamic' public sphere which enables a large segment of diverse Muslims to make their voices heard in civic debate and public life, thus facilitating modern and distinctively open senses of political and religious identity (Salvatore and Eickelman 2004). Being embedded in a combination of public display and public discourse, public Islam constitutes a process of ordering and rationalizing that is expressed in Islamic terms and coheres into a unified normative principle. In so doing, it plays a significant role in channelling social change, securing social order and promoting grass-roots democratization in Muslim societies (Salvatore 1996). In other words, public Islam is a process that sheds some light on the significance of religion in the dynamics of public life of contemporary Muslim societies.

The growth of religion's public visibility in today's politics is actually not unique to Muslims. As Casanova (1994) has argued, religions in the globalizing era have entered the public sphere and the arena of political contestation to participate in the very struggles that define and set the

\footnotetext{
16 Interview with Dawamuddin Masdar, an NU leader in Kebumen, Kebumen, 9January 2008
} 
modern boundaries between the private and public spheres; between system and life-world; between family, civil society and state; and between nations, states, civilizations and the world system. It is the era when the wall of secularization separating the secular and religious realms - which entails the privatization of religion - breaks down and faces a serious challenge. For Casanova, the appearance of religions in the public spaces of the globalizing era facilitates a new institutionalization of processes of practical rationalization and thus the fading of boundaries between the private and the public. By entering the sphere of public communication, religions are induced to a 'reflexive rationalization' of the life world, which entails a reconfiguration of the private-public dichotomy and of its boundaries (Casanova 1994:6-10, 228-9).

The burgeoning of public Islam is related to the rapid current of modernization and globalization and the nation's ongoing democratic consolidation. Following the shift towards a consumerist society as a result of globalization, religion is experiencing commodification as piety becomes part of the drama of self-identity and representation, and the statement of the self in the public space. As an alternative to religious radicalism, it offers Muslims a way to actualize religious beliefs and values while still following the path of modernity and globalization, without plunging into violence and joining a cycle of militancy. Democratic values, which form the foundations of practical Islam and the politics of contemporary Muslim society, suggest that being a democratic Muslim is no longer an oxymoron (Nasr 2005).

The complex relationship between Islam and democracy is made manifest when its symbols have assumed a greater significance in the dynamics of local politics. The importance of religious symbols in local politics lies in their ability to legitimize elites in power, and their collaborators, as they attempt to respond to challenges from the opposition, including militant Islamists. This has led those in power to appropriate religious symbols and Islamist idioms for the instrumental purpose of claiming the mantle of Islam and delegitimizing the Islamist opposition, while simultaneously producing more harmonious state-society relations (Nasr 2001; Liow 2009). By mobilizing religious symbols, new political elites from a santri background with links to prominent ulama and their pesantren were in effect renegotiating the boundaries of political power, economic arrangements and group identities. Interestingly, when a multiplicity of actors has the opportunity to interpret the symbols, each in accordance with their own interests, the Islamists' attempt to dominate the symbolic 
interpretation and thereby transform the country's secular democracy into an Islamic state has increasingly lost ground. Religious symbols have irrefutably been distanced from their religious moorings and from narrow, Islamist understandings, in favour of pragmatic political purposes.

This phenomenon often looks like a paradox. Democracy requires a liberation of public spaces from the domination of narrow religious, ethnic and primal sentiments. If these were to resurface in the political arena they could affect the very process of democratic consolidation. But on the other hand, religious symbols may play a pivotal role in political mobilization. They can legitimize the ruling elite and provide the means for them to counter and deligitimize their opposition, including the militant Islamists. The situation is rendered more complex by the fact that democracy cannot deny interest groups access to those same symbols, which they can then use to pursue their own narrow, group-specific interests. In exchange for support in local elections, for instance, regional political leaders may well exploit religious symbols and align themselves with the religious majority in decision making. By ignoring the basic principles of democracy, regional autonomy can become more corrupt and exploitative than the highly centralized government of the New Order, and thus become a stumbling block to achieving the public good.

When Indonesia adopted regional autonomy and Jakarta decentralized many (but not all) of its political and financial powers, the matrix of power relations became more complex. The nexus between the interests of regional elites to capture power, competition for resources, and ethnic-cum-religious divisions seems to have driven the dynamics of local politics in Indonesia's many different regions. All these phenomena are in fact symptoms of the weakening of the central state, which interestingly does not automatically result in more democratization, good governance and the strengthening of civil society. As Henk Schulte Nordholt and Gerry van Klinken have shown, despite the process of decentralization, political and economic development at the regional level seemed doomed. Its process is challenged by bureaucratic sabotage, corrupt power politics, short-term opportunism and the absence of a widely shared vision of the future. Moreover, the relative weakness of civil society has accompanied the emergence of new forms of authoritarian rule and the continuity of existing patrimonial patterns. Particular bureaucratic and political elites mobilized ethnic-cum-religious sentiments to achieve their goals (Schulte Nordholt and Van Klinken 2007a). It should be noted, however, that approaching the issue from a linear model of democratization, these 
authors are apparently more tempted to underscore the paradoxes of decentralization in post-Suharto Indonesia at the expense of the more nuanced dynamics of the process itself.

The case of Kebumen is again worth noting in this context. Rustriningsih represents the middle class's ability to make use of religious symbols, ideologies and solidarities and give them multiple interpretations to legitimize their own claims at a time when democratic idioms have increasingly gained ground in Indonesian provincial towns. As a successful, 35-yearold woman wearing a colourful headscarf and a fashionable two-piece suit (with a long skirt) for her public performances, Rustriningsih's new image spoke loudly of the compatibility of Islam with modernity. She responded to the harsh critiques of her Islamist rivals, especially those in the Front Thariqatul Jihad (FTJ), who questioned her abangan background as being unfriendly to Islam. She also challenged Islamists' and conservative Muslims' repudiation of women in public spaces, and their right to a political position in the male-dominated region of Kebumen. The wearing of a headscarf certainly did not indicate Rustriningsih's agreement with the Islamists' agenda, by which public moral order and personal behaviour should be governed according to the precepts of a militant Islamist ideology. Rather, her headscarf can be seen as evidence of the gender struggle to reconstruct the segregating social norms that subordinate women. Thus Rustriningsih was exercising public agency to deconstruct social taboos, and to reconfigure the collective social imagination to accept that being a good Muslim woman does not require withdrawal from public spaces and social relations (Mahmood 2005:5-10). Becoming a good Muslim woman may instead mean having the courage to stand tall in public, and to lead others through change for the better. Once Rustriningsih started wearing a headscarf she no longer hesitated to talk about good governance, democracy and poverty reduction.

The importance of religious symbols in the dynamics of local politics following Suharto's demise appears also to be linked to incremental efforts by district- and municipal- level governments to redefine their regional identities. Suharto's highly centralized New Order government discouraged real regional identity, and maintained close control over the resources of the nation's various regions, as well as their political and economic development. In fact, 'the New Order government was ethnocentrically controlled by the Javanese, and therefore, all forms of Javanese culture supported and underpinned the regime's cultural policies and imaginings' (Clegg 2008:177). This 'Javanization' of Indonesia was increasingly seen as exerting a strangehold on the lives of the Indonesian people. 
Especially outside of Java, many felt that they had never really enjoyed the fruits of 30 years of New Order development, but instead bore the brunt of corruption, collusion and nepotism from the centre (Priyambudi Sulistiyanto and Erb 2005). Law No. 22/1999 on local autonomy was therefore welcomed with enthusiasm. This law drastically limited the authority of the central government, and devolved considerable authority to district governments, thereby strengthening the position of the local government at the district and municipal levels (Pratikno 2005). Despite the fact that regional, religious and ethnic identity politics assumed much greater importance, decentralization is widely recognized as a major and necessary step towards nurturing a flourishing democracy by giving space for people to participate in local political processes (Priyambudi Sulistiyono and Erb 2005; Schulte Nordholt and Van Klinken 2007a).

Local-elite political groups adopted a range of strategies to redefine and strengthen regional identity as a means of increasing their electoral support. As well as reinventing historical legacies and memories, they mobilized religious symbols and other forms of cultural capital, including support from the ulama. As evident in the case of Martapura, Rudy Ariffin sought to secure sympathy and support from the ulama shortly after he was elected as the district head in 2000 . The most charismatic ulama in Martapura, Guru Zaini, did not initially support Ariffin and his running partner, Mawardi Abbas. Yet to have Guru Zaini's support could be enormously important. As the murshid (Sufi adept) of the Sammaniyah Sufi Order, he had wide influence among Muslims throughout Kalimantan. Ariffin made all-out efforts to persuade Guru Zaini. His relentless efforts were blessed with a stroke of good luck when he was made responsible for arranging President Abdurrahman Wahid's visit to Sekumpul in 2001, thus providing him a golden opportunity to make closer contact with Guru Zaini. ${ }^{17}$

Ariffin's drive to reinforce the image of Martapura as the front porch of Mecca underpinned his proposal to enact shariah by-laws. For the political elite of Martapura, the complete congruence of Islam and Banjarese culture is unrefutable. Referring to the thesis proposed by local anthropologist Alfani Daud, the main conceptor of the by-laws insisted that 'Islam is Banjar and Banjar is Islam.' In his opinion, however, the pressures of rapid modernization and globalization and Jakarta-centric

\footnotetext{
17 Interview with Anang Armawan, former bupati candidate, Martapura, 10 February 2008, and with Fauzan Saleh, the chairman of the executive council of the NU branch in Martapura, 13 February 2008.
} 
development had resulted in the fading influence of Islam as the most important source of reference among the Banjarese people. As a consequence, social problems and moral diseases such as gambling, adultery, drug addiction and other forms of 'vice' had spread widely, especially among Martapura's younger generation. He argued that this problem is of concern not only to the government, but also to ulama and ordinary citizens, and thus urged the local government to enact the by-laws. ${ }^{18}$

Matters assumed a greater urgency when a paramilitary organization, Garusikat (the Movement of Muslims to Remove Social Ills), was established with support from such conservative ulama as Anang Jazouly Seman, and actively took to the streets calling for the shariah. ${ }^{19}$ Its organizational structure and operational concept were proposed by Badru 'Ain Sanusi al-Afif, a former NGO activist who was also active in advocacy programmes. A daring religious teacher, Suhaimi, was appointed as the group's commander, backed-up by former influential thugs, including Hasan Sinso. The police saw Garusikat as a challenge to their authority, and eventually responded by sponsoring the establishment of a similar organization named Dalas Hangit under the leadership of Utuh Hirang, another former thug. There was considerable tension between the two groups, resulting in actual conflict. They only reached peaceful agreement after mediation by Guru Zaini. ${ }^{20}$

The shariah by-laws allowed Ariffin to systematically locate Islam at the epicentre of the town's bureaucratic orbit. What has been called the bureaucratization of Islam has taken place through a conscious decision to Islamize the government, and by the policies adopted to achieve this end. ${ }^{21}$ When Martapura started promulgating shariah by-laws, every part of the bureaucratic machinery began competing to demonstrate its superior commitment to Islam. All manner of bureaucratic cogs in the government machinery became active in organizing religious lectures and other religious activities. To strengthen his policy of Islamizing the bureaucracy, Ariffin then issued a circular recommending all female civil servants in the Banjar administration and related institutions throughout the region

\footnotetext{
18 Interview with Mashuri, former chief of the social office, and now of the economic office, at the Banjar district, 16 February 2008.

19 Interview with Mawardi Abbas, Martapura, 16 February 2008.

20 Interview with Rizki Wijayakusuma, former NGO activist, Martapura, 19 February 2008.

${ }^{21}$ On the notion of the bureaucratization of Islam and how this policy has begun to work out, especially in the context of Malaysia under Mahathir's government, see Liow 2009:46-8.
} 
to wear headscarves. Although this only had the strength of a recommendation, the letter made no allowance for women working in government offices who happened to be Christians, Hindus or Buddhists. They should all wear headscarves. They were made to feel uncomfortable if they did not wear headscarves in their interactions with superiors or other civil servants. ${ }^{22}$

When Khairul Saleh replaced Ariffin, the policy of redefining regional identity and Islamizing the bureaucracy by insisting on the need for shariah by-laws continued unabated. He ratified a proposal by the local legislators for a regulation requiring the insertion of Jawi (Malay-Arabic) script on office nameplates in all of Martapura's government offices. He claimed that this policy was part of his drive to disseminate the Islamic ethos throughout all government units and offices in the region, an ethos that packages the internalization of piety, honesty and good performance. His rationale was that the Jawi script uses the Arabic alphabet to write the Malay language, and this script had once been common in the Banjar Sultanate and other Malay Islamic kingdoms. Its significance for Saleh was that the Jawi script is identical to the alphabet of the Qur'an, which is the ultimate guide to Muslim behaviour in both public and private life. ${ }^{23}$ Saleh is known as a qari (Qur'anic reciter in rhythmic tones), and he intersperses his public speeches or briefings with fluent quotations from the Qur'an and the prophetic traditions (Hadiths). Reinforcing Islam's public voice in Martapura's bureaucratic sphere, salawat (salutation to the Prophet Muhammad) and Qur'anic verses are often used instead of patriotic and national songs as interludes at important government events. Every morning, civil servants in the Banjar district listen to a short sermon, piped to their offices, on the importance of such virtues as piety, transparency, honesty and the ethos of meritocracy for the success of regional development, laced with Qur'anic quotations.

\section{Conclusion}

The mushrooming of Islamic symbols in the public spaces of Indonesian provincial towns after Suharto should be understood in relation to Indonesia's democratization process and the social mobility generated by

\footnotetext{
22 Interview with Masnur Manurung, a Christian female civil servant in the Banjar regional administration office, 12 February 2008.

${ }^{23}$ Interview with Khairul Saleh, the regent of Banjar, Martapura, 21 February 2008.
} 
the country's economic growth. The growing public visibility of Islamic symbols in towns like Kebumen or Martapura should not be seen as indications of the spread of a stricter, scripturalist interpretation of Islam. While it has often been argued that the anxieties caused by globalization make people seek comfort in stricter interpretations of religious texts, I have tried to show that economic development in Indonesia's provincial towns is also generating a more pragmatic and consumerist, lifestyleoriented attitude towards Islam. A new middle class is looking to Islam for inspiration both to claim distinction and social status and to legitimize their consumptive lifestyle. The newly pious become active negotiators between the global and the local as well as between the cosmopolitan centre and the hinterland. They also play a pivotal role as an agency that liberalizes religion from its traditionally subservient, passive and docile posture by turning it into a source of moral legitimacy and distinction to represent a modern form of life.

The growing interest of the middle class in a market-friendly, Islambased lifestyle has spread to a large and diverse segment of Indonesian Muslims, including those on the economic margins who show a fascination with the cultural codes associated with the wealth and power of the new elites. The expansion of market demands and opportunities for commercial products related to Islam facilitates the phenomenon of religious commodification, which is very much to do with the way religion is packaged and offered to a broader audience. The role of the middle class is crucial, not only as loyal consumers but also as commercial agents that widely distribute the 'Islamic' products that follow the latest trends to reach remote areas in the contryside. They are at the forefront to transform Islam into a symbolic commodity which is not totally uprooted from tradition and culture, but relevant to upwardly mobile consumer demands for lifestyle, modesty and enjoyment. The end result of this process is determined by the way in which Indonesian provincial towns are willing to distance themselves from the past as they embark upon a new modernity.

Given its intimate relationship with locality, tradition, modernity as well as globalization, Islam has increasingly assumed a greater importance for local politics. Political elites have used Islamic symbols for the instrumental purpose of extending their political legitimacy and mobilizing constituency support, in a political environment of open competition and increased public participation in decision making. In this process religious symbols have irrefutably been distanced from their religious moorings and narrow, Islamist understandings, in favour of pragmatic 
political purposes. Thus the adoption of the headscarf (jilbab) by Kebumen's district head, Rustriningsih, in her official performance remains an empty gesture, or even a middle-class elitist symbol, unless the jilbab has become an authentic expression of her lifestyle. Seen from a similar perspective, the application of shariah bylaws in Martapura is best understood not as evidence of the growing influence of Islam in politics, but rather as the manoeuvres of the town's political elites in their efforts to secure their own interests. The by-laws nonetheless allowed the elites to systematically attempt to locate Islam at the heart of the town's bureaucratic orbit. Islam has emerged as a source of legitimacy for political leaders, but always in relation to tradition and local culture. 